\title{
Acalculous cholecystitis associated with Hantaan virus: A case report
}

\author{
Sung Hyun Kim, Sejin Park, and Jangkyu Choi \\ Department of Surgery, Armed Forces Capital Hospital, Seongnam, Korea
}

\begin{abstract}
Acute acalculous cholecystitis (AAC) still remains one of the most elusive diagnoses and occurs in various conditions. Although AACs caused by viral infections are rare, various viruses have been revealed to cause AAC. Here we present a case in which a man suffered from AAC caused by a Hantaan virus infection. A 35-year-old man was referred to the emergency room for myalgia and fever that began 4 days ago. He suffered oliguria and abdominal pain for 2 days. At the time of his visit to the emergency room, he experienced a fever that spiked up to $38.3^{\circ} \mathrm{C}$. An initial blood sample objectified the following pathologic results: white blood cells $-10260 / \mu \mathrm{l}$; C-reactive protein $-6.76 \mathrm{mg} / \mathrm{dl}$; total bilirubin - $1.7 \mathrm{mg} / \mathrm{dl}$; AST - $90 \mathrm{IU} / \mathrm{L} ;$ ALT - $233 \mathrm{IU} / \mathrm{L}$. In the computed tomography, bilateral perirenal fluid collections and bilateral flexural effusion were shown and acute hepatopathy and cholecystopathy were also shown. Because there was no definite tenderness around the patient's right upper quadrant from physical examination and his cholecystopathy looked like it was from secondary change according to acute hepatopathy, we decided to perform conservative care without surgical treatment. The following day, in viral antibody test, Hantaan virus antibody was detected. After conservative management, the patient's condition improved and his laboratory findings were stable. The patient was discharged on the $10^{\text {th }}$ day at the hospital stay without any symptoms. The Hantaan virus infection should be suspected as a causative agent of $A A C$, especially when there is abnormal liver function tests and abdominal pain. (Ann Hepatobiliary Pancreat Surg 2019;23:278-281)
\end{abstract}

Key Words: Cholecystitis; Hemorrhagic fever with renal syndrome; Hantavirus; Hantaan virus; Conservative care

INTRODUCTION

Acute acalculous cholecystitis (AAC) is defined as the inflammation of the gallbladder wall in the absence of stones or sludge. ${ }^{1}$ It accounts for about $10 \%$ of acute cholecystitis. $^{2}$ However, AAC still remains one of the most elusive diagnoses because it occurs in various conditions such as trauma, post-operation, burn, sepsis, fasting and so on. ${ }^{1}$ Viral infections also are one of the causes inducing ACC. Although AACs caused by viral infections are rare, various viruses have been revealed to cause AAC. Above them, AAC induced by hantavirus is extremely rare. Only few cases of AAC associated with hantavirus infection have been reported. ${ }^{3-5}$ Here we present a case in which a man suffered from AAC caused by a Hantaan virus, which is one of the subtypes of hantavirus.

\section{CASE}

A 35-year-old man was referred to the emergency room at the end of August for myalgia and fever that began 4 days ago [=post-onset of symptoms (POS) 0]. He suffered oliguria and abdominal pain for 2 days. At the time of his visit to the emergency room, he experienced a fever that spiked up to $38.3^{\circ} \mathrm{C}$. Blood pressure was $112 / 57 \mathrm{~mm}$ $\mathrm{Hg}$, respiratory rate was 18 breaths/min and weight of the patient was $81.0 \mathrm{~kg}$. Numeric pain rating scale (NRS) was 3. However, abdominal palpation revealed no tenderness. An initial blood sample objectified the following pathologic results: white blood cells $(\mathrm{WBC})$ - 10260/ $\mu$; C-reactive protein (CRP) $-6.76 \mathrm{mg} / \mathrm{dl}$; total bilirubin $-1.7 \mathrm{mg} /$ $\mathrm{dl}$; aspartate aminotransferase (AST) - $90 \mathrm{IU} / \mathrm{L}$; alanine aminotransferase (ALT) - $233 \mathrm{IU} / \mathrm{L}$; and alkaline phosphatase (ALP) - $638 \mathrm{IU} / \mathrm{L}$. Although specific analysis of urine

Received: March 29, 2019; Accepted: March 29, 2019

Corresponding author: Jangkyu Choi

Department of Surgery, Armed Forces Capital Hospital, 177 Saemaeul-ro, Seongnam 13574, Korea

Tel: +82-31-902-6249, Fax: +82-31-725-5114, E-mail: dark8262@naver.com

Copyright (C) 2019 by The Korean Association of Hepato-Biliary-Pancreatic Surgery

This is an Open Access article distributed under the terms of the Creative Commons Attribution Non-Commercial License (http://creativecommons.org/ licenses/by-nc/4.0) which permits unrestricted non-commercial use, distribution, and reproduction in any medium, provided the original work is properly cited. Annals of Hepato-Biliary-Pancreatic Surgery • pISSN: 2508-5778 - elSSN: 2508-5859 
analysis (specific gravity) was 1.030 , the serum creatinine was still normal on POS 4 , at $0.91 \mathrm{mg} / \mathrm{dl}$. The chest radiograph was normal. The patient was admitted under r/o hemorrhagic fever with renal syndrome (HFRS). Korean hemorrhagic fever virus studies ( $R$. tsutsugamushi $\mathrm{Ab}$, Hantaan virus $\mathrm{Ab}$ and Leptospira $\mathrm{Ab}$ ) were done.
One day later (POS 5), the abdominal pain was aggravated (NRS 5) and fever spiked up to $38.7^{\circ} \mathrm{C}$. The patient gained weight about $3.5 \mathrm{~kg}$ and diuresis was only $690 \mathrm{ml} / 24 \mathrm{~h}$. U/A S.G revealed 1.032. The blood sample objectified the following results: WBC $-11760 / \mu \mathrm{l}$; CRP $10.65 \mathrm{mg} / \mathrm{dl}$; total bilirubin - $2.2 \mathrm{mg} / \mathrm{dl}$; direct bilirubin -
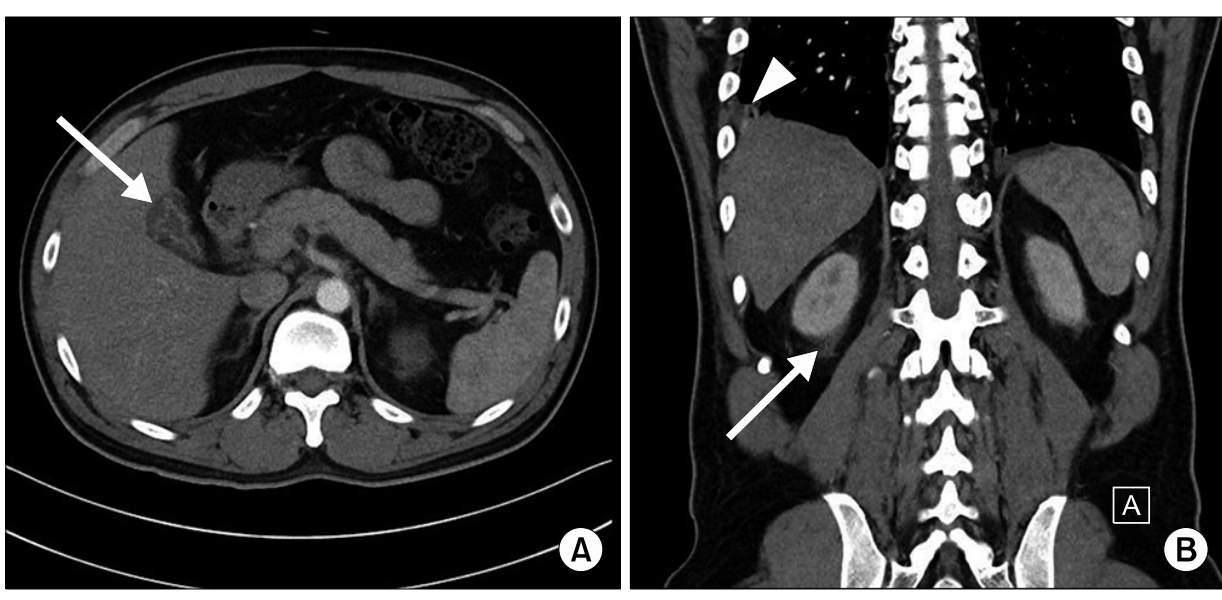

Fig. 1. Computed tomographic findings of the patient. (A) White arrow: pericholecystic fluid and subserosal edema with halo sign. (B) White wedge: pleural effusion, white arrow: perirenal fluid collections.

Table 1. Biological and clinical parameters of the patient

\begin{tabular}{|c|c|c|c|c|c|c|c|}
\hline POS (day) & 4 & 5 & 6 & 7 & 8 & 11 & 34 \\
\hline WBC $\left(10^{3} / \mu \mathrm{l}\right)$ & 10.26 & 11.76 & 9.94 & 8.05 & & 9.26 & 7.90 \\
\hline Neutrophil (\%) & 81.7 & 82.7 & 81.7 & 72.3 & & 68.5 & 47.7 \\
\hline $\mathrm{Hb}(\mathrm{g} / \mathrm{dl})$ & 14.5 & 13.8 & 13.1 & 12.7 & & 14.0 & 15.5 \\
\hline Plt $\left(10^{3} / \mu \mathrm{l}\right)$ & 224 & 209 & 206 & 248 & & 342 & 200 \\
\hline BUN (mg/dl) & 10.0 & 8.8 & 5.3 & 4.0 & & 8.5 & 11.1 \\
\hline $\mathrm{Cr}(\mathrm{mg} / \mathrm{dl})$ & 0.91 & 0.97 & 0.67 & 0.62 & & 0.74 & 0.76 \\
\hline $\mathrm{Na}(\mathrm{mmol} / \mathrm{L})$ & 143 & 142 & 138 & 143 & & 142 & 143 \\
\hline $\mathrm{K}(\mathrm{mmol} / \mathrm{L})$ & 4.0 & 3.9 & 3.8 & 3.8 & & 4.4 & 5.0 \\
\hline CRP (mg/dl) & 6.76 & 10.65 & 10.69 & 10.16 & & 1.15 & 0.04 \\
\hline Alb (g/dl) & 3.9 & 3.7 & 3.3 & 3.1 & 3.2 & 3.8 & 4.3 \\
\hline LDH (IU/L) & 413 & 421 & & & 184 & & \\
\hline T. bil (mg/dl) & 1.7 & 2.2 & 2.1 & 1.9 & 1.7 & 0.9 & 0.7 \\
\hline D. bil (mg/dl) & & 1.8 & 1.7 & 1.5 & & & \\
\hline AST (IU/L) & 90 & 43 & 31 & 35 & 66 & 67 & 20 \\
\hline ALT (IU/L) & 233 & 157 & 123 & 100 & 113 & 117 & 24 \\
\hline ALP (IU/L) & 638 & 591 & 421 & 391 & 399 & 374 & 185 \\
\hline U/A S.G & 1.030 & 1.032 & & & & & \\
\hline $\mathrm{BP}_{\max }(\mathrm{mmHg})$ & $112 / 57$ & $124 / 62$ & $115 / 73$ & $130 / 61$ & $140 / 78$ & $123 / 76$ & \\
\hline $\mathrm{HR}_{\max }$ (beats/min.) & 74 & 77 & 91 & 57 & 68 & 60 & \\
\hline $\mathrm{RR}_{\max }$ (breaths/min.) & 18 & 18 & 16 & 15 & 16 & 14 & \\
\hline $\mathrm{BT}_{\max }\left({ }^{\circ} \mathrm{C}\right)$ & 38.3 & 38.7 & 37.9 & 37.1 & 37.6 & 36.8 & \\
\hline Weight (kg) & 81.0 & 84.6 & 84.4 & 84.9 & 83.5 & 79.5 & \\
\hline $\mathrm{U} / \mathrm{O}(\mathrm{ml} / 24$ hours $)$ & & 690 & 1800 & 2750 & 3300 & & \\
\hline Pain score & 3 & 5 & 4 & 3 & 2 & & \\
\hline
\end{tabular}

POS, post-onset of symptoms; WBC, white blood cell; Hb, hemoglobin; Plt, platelet; BUN, blood urea nitrogen; $\mathrm{Cr}$, creatinine; CRP, c-reactive protein; Alb, albumin; LDH, lactate dehydrogenase; T. bil, total bilirubin; D. bil, direct bilirubin; AST, aspartate aminotransferase; ALT, alanine transaminase; ALP, alkaline phosphatase; U/A S.G, urinalysis specific gravity; BP, blood pressure; HR, heart rate; RR, respiratory rate; $\mathrm{BT}$, body temperature; $\mathrm{U} / \mathrm{O}$, urine output 
$1.8 \mathrm{mg} / \mathrm{dl} ;$ AST - $43 \mathrm{IU} / \mathrm{L} ;$ ALT; $157 \mathrm{IU} / \mathrm{L}$; and ALP $591 \mathrm{IU} / \mathrm{L}$. In the computed tomography, bilateral perirenal fluid collections and bilateral pleural effusion were shown and pericholecystic fluid and subserosal edema with halo sign were also shown. (Fig. 1) Although abdominal pain was aggravated there was no definite tenderness around the patient's right upper quadrant from physical examination. Because his cholecystopathy looked like acute acalculous cholecystitis from secondary change according to acute hepatopathy, we decided to perform conservative care without surgical treatment. At night of the day (POS 5), Hantaan virus antibody was detected in the viral antibody test.

After conservative management, the patient's condition improved. Urine output increased rapidly to $3300 \mathrm{ml} / 24$ hr on POS 8 and body weight decreased to $79.5 \mathrm{~kg}$ on POS 11. In the meantime, his laboratory findings were getting better. Comparative change of the laboratory findings are summarized in Table 1. The patient was discharged on POS 11 without any symptoms. The patient visited the outpatient department on POS 34 and the clinical examination was normal at that time.

\section{DISCUSSION}

Since the 1980s, when the Hantaan virus was reported, lots of studies about hantavirus were performed. ${ }^{6}$ In the present, various viruses apart from the hantaan virus are reported as a subtype of the hantavirus throughout the world. Hantavirus infection is presented with various symptoms such as fever, malaise and myalgia. It appears as two clinical syndromes: hemorrhagic fever with renal syndrome (HFRS) or hantavirus cardiopulmonary syndrome (HCPS). ${ }^{7}$

One of the mechanisms in the pathogenesis of hantavirus is plasma leakage. Hantavirus causes vascular permeability-based diseases and primarily infect endothelial cells. ${ }^{8}$ It leads to edematous swelling of organs such as kidney and lung. These are presented as pleural effusion and perirenal fluid collection.

Sometimes, this edematous change occurs in the gallbladder. A study reported that gallbladder wall thickening occurs in HFRS patients and it is related to the severity of the disease. Especially, more than $4 \mathrm{~mm}$ of gallbladder wall thickening is related to its severity. ${ }^{9}$ Although an ul- trasonography was not performed in our patient, the computed tomography showed that his gallbladder wall thickness was more than $4 \mathrm{~mm}$.

However, not every case with gallbladder wall thickening experiences acalculous cholecystitis. A case of acalculous cholecystitis related to hantavirus infection is rare. To the best of our knowledge, there are 2 case reports and 1 case series. ${ }^{3-5}$ By reviewing the previous cases, all of the patients underwent conservative care without cholecystectomy. AAC originated from viral disease tend to undergo conservative management. Especially, because most of ACC originated from viral disease, supportive care is recommended in children. ${ }^{10}$ In our case, the patient was discharged after conservative management.

One interesting finding in our case was that a Hantaan virus subtype caused ACC. The previous cases were reported from Europe and they were infected by the puumala virus subtype, a form of hantavirus. After Hantaan virus was first reported in the 1980s, about 30 subtypes of hantavirus have been reported. ${ }^{7}$ However, other than the puumala virus, there was no report that hantavirus induced ACC. Our case showed possibility that other subtypes of hantavirus could induce ACC.

In conclusion, this case relates the occurrence of ACC to the Hantaan virus subtype. As hantavirus causes plasma leakage leading to ACC, hantavirus induced ACC might be treated by supportive care without surgery. In addition, subtypes of hantavirus other than Hantaan or puumala subtypes could induce ACC. Further studies are needed.

\section{REFERENCES}

1. Barie PS, Eachempati SR. Acute acalculous cholecystitis. Gastroenterol Clin North Am 2010;39:343-357, x.

2. Huffman JL, Schenker S. Acute acalculous cholecystitis: a review. Clin Gastroenterol Hepatol 2010;8:15-22.

3. Fröhlich R, Römmele U. [Acalculous cholecystitis in hantavirus infections]. Dtsch Med Wochenschr 2013;138:1255-1258. German.

4. Keyaerts E, Ghijsels E, Lemey P, Maes P, Zachée P, Daelemans $\mathrm{R}$, et al. Plasma exchange-associated immunoglobulin m-negative hantavirus disease after a camping holiday in southern france. Clin Infect Dis 2004;38:1350-1356.

5. Nicolas JB. Acalculous cholecystitis associated with hemorrhagic fever with renal syndrome. Acta Clin Belg 2015;70:377-381.

6. Lee HW, Lee PW, Johnson KM. Isolation of the etiologic agent of Korean hemorrhagic fever. 1978. J Infect Dis 2004;190:17111721.

7. Avšič-Županc T, Saksida A, Korva M. Hantavirus infections. Clin Microbiol Infect 2019;21S:e6-e16.

8. Mackow ER, Gavrilovskaya IN. Hantavirus regulation of endo- 
thelial cell functions. Thromb Haemost 2009;102:1030-1041.

9. Kim YO, Chun KA, Choi JY, Yoon SA, Yang CW, Kim KT, et al. Sonographic evaluation of gallbladder-wall thickening in hemorrhagic fever with renal syndrome: prediction of disease severity. J Clin Ultrasound 2001;29:286-289.

10. Poddighe D, Sazonov V. Acute acalculous cholecystitis in children. World J Gastroenterol 2018;24:4870-4879. 